\title{
A Survey on Technology used in Higher Secondary EFL Class in Bangladesh
}

\author{
Kaniz Fatema, ${ }^{1}$ Negar Sultana ${ }^{2}$ \\ ${ }^{1}$ M.A. in Foreign Linguistics and Applied Linguistics, Nanjing Tech University of China \\ ${ }^{2}$ M.A in English Language and Literature, Southeast University of Dhaka, Senior Teacher of \\ MAHAAD
}

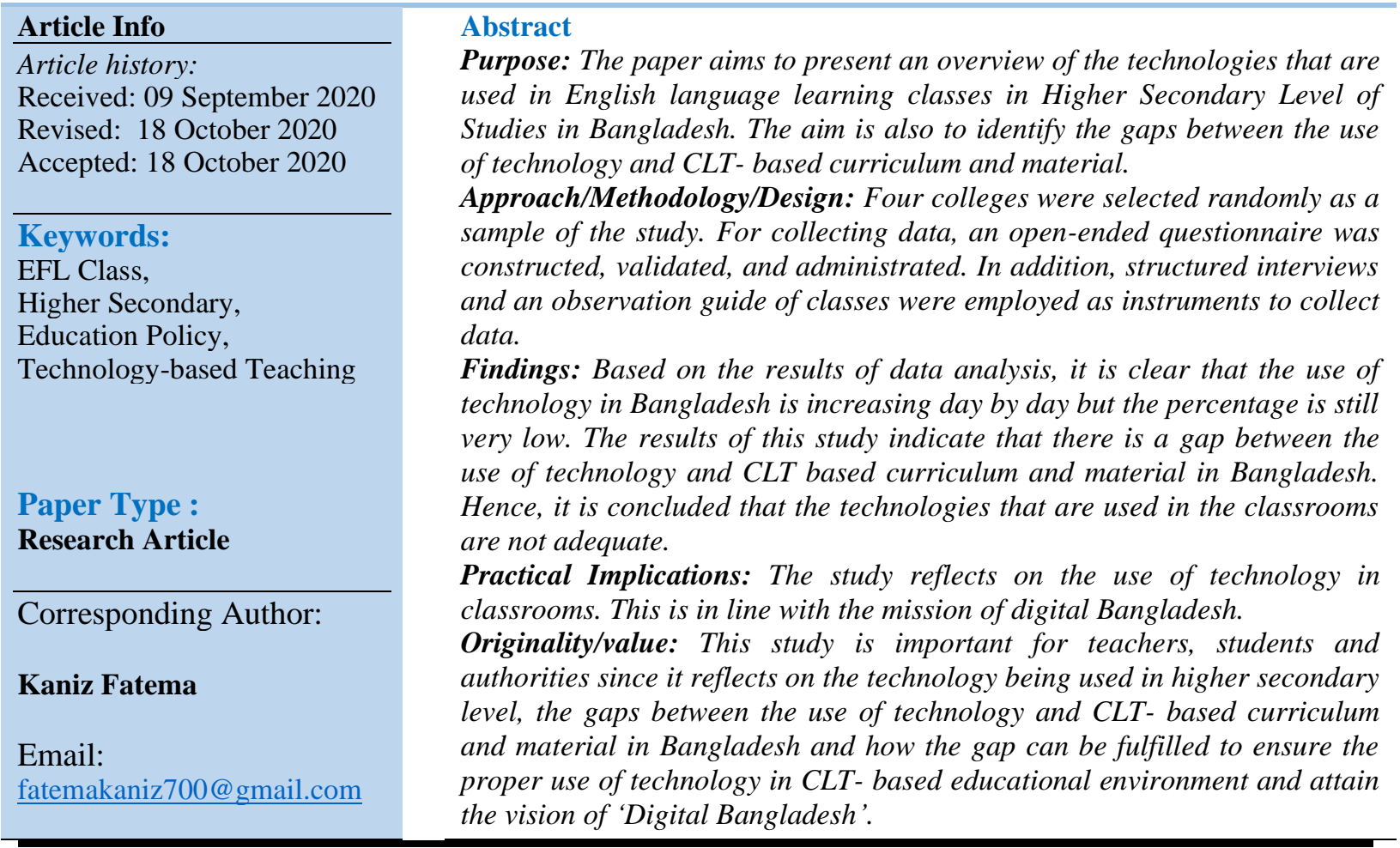

\section{Introduction}

In Bangladesh, the National Education Policy in 2010 brought changes in the English curriculum with more focus on the need to learn English for communicative purposes (National Curriculum, 2012, p.2). "The curriculum focuses on teaching/learning English as a skill-based subject so that learners can use English in real-life situations by acquiring necessary language skills as well as knowledge, learning about cultures and values, developing positive attitudes, pursuing higher education and having better access to local and global employment" (National Curriculum, 2012, p.2). Many activities — such as dealing with secondary and higher secondary education; managing educational research and training; 
making policy and reformations; developing curriculum; and so on are handled by the MoE in Bangladesh (MoE, 2007-8). Implementing any change for developing the curriculum, the NCTB (National Curriculum and Textbook Board), a department of MoE, plays a major role. For example, a change in English curriculum-introducing CLT to higher secondary level was propelled by the NCTB (MoE, 2007-8).

With the vision of Digital Bangladesh by preparing the 'Digital Bangladesh Strategic Priorities' and embedding the priorities into the country's $6^{\text {th }}$ Five Year Plan, it is important to re-examine the current technologies that are used in the classrooms in order to be in harmony with this ambitious vision. Technology leads learners to explore the virtual class without any binding for learning language from the traditional four walled classroom. Interactive whiteboard, multimedia projector, Light pen, Online-based lecture, Online courses of virtual classes and certificates from different top universities of the world, E-book, CALL (Computer Assisted Language Learning), MALL (Mobile Assisted Language Learning), TV channels, social networking websites, MOODLE, Podcast, web quest, website, e- library, ejournals, e-encyclopedia, e-dictionary and some more virtual resources are the technologybased resources commonly used for effective teaching and learning language in different form. Using the technology-based equipment in the classroom or online resources, the future generations of Bangladesh will successfully handle the challenges or barriers in higher education. The Govt. of Bangladesh and Education Ministry are doing their best to make sure that technology is used in every level of its education system, such as ensuring projectorbased classroom, computer lab in every school and many more. Present language classrooms are immensely different from that of the mid - to late 20th century (Eaton, 2010). This study is an attempt to find out the technologies that are used in Bangladesh in H.S.C level for educational purpose, especially in English language class and the gap between the use of technology and CLT based curriculum and material in Bangladesh.

In Bangladesh, educational technology is rarely used in classrooms. ICT could make learning more interesting, authentic and much easier than the traditional way of teaching. As English is taught in Bangladesh, in two streams, English $1^{\text {st }}$ paper mainly deals with the exercises of listening, speaking, reading, and writing skills. English $2^{\text {nd }}$ paper focuses on the grammatical rules and exercises to learn about the correct use of language. As Bangladesh is an overpopulated country where teacher and student ratio seems oddly unequal, technology can play a great role both for the teacher to guide the class and for the student to understand the lesson more easily and vividly. The main purpose of this paper is to find out the use of technology for educational purpose and how to enhance the use of technology in higher secondary level. At present, Government of Bangladesh is making sure every institution has computer or laptop and projector.

\section{Literature Review}

Different surveys show various uses of technology in education and language teaching/learning in particular. A survey conducted by Microsoft found that $82 \%$ students aged between 16 and 18 years used Facebook every day (Coughlan, 2011). Rheingold (1993) 
argued that researching online communities is like looking into a social space such as a café, the need for people to fill a gap that has arisen with the process of cultural shifts that have led to the disappearance of informal meeting places in modern society'. Like many other countries of the world, Bangladesh has started to introduce latest technologies such as ICTs in major sectors of the country (Rahman, Paul, Hasan, 2012, p.8977). In order to do so, in 2009, Bangladesh launched an ICT plan (Rahman, Paul, Hasan, 2012, p.8977).

The Swedish National Agency for Education, Skolverket, has a specified curriculum for the compulsory schools, preschool and the recreation centre in which the following statements can be found: "Teaching should be adapted to each pupil's circumstances and needs. It should promote the learners' further learning and acquisition of knowledge based on learners' backgrounds, earlier experience, language and knowledge." The American Council on the Teaching of Foreign Language (ACTFL, 2013) noted that technology has been used to both assist and enhance language learning. Bangladesh is also trying its best to leave behind the traditional methods of teaching and become part of the virtual world where education is given with ultimate power of freedom. Being a part of this challenge, Bangladeshi educators must focus more on skill-oriented and interactive activities. Though "Bangladesh government made ICT policy for the better use of it and it's a part of Digital Bangladesh: Vision 2021", the higher educational institutions are still not getting enough modern technological facilities for effective teaching and learning (Hossain, Salam, \& Shilpi, 2016, p.131). In addition, Maniruzzaman and Rahman (2008) indicated the lack of teachers training and insufficient audio-visual equipment hamper the use of instructional aids in EFL classes.

The crisis of English language teaching and learning and lack of training in CLT in Bangladesh require urgent responses from the government, as well as from the country's international development partners. Bangladeshi teachers need professional support in developing their own English language and teaching skills. On the basis of the outcomes from this pre-pilot project, open and distance learning has the potential to be an effective technique to support teachers' professional development and to bring about changes in classroom practice. In addition, the use of new mobile technology has been shown to facilitate access to learning as well as improving the quality of teacher education and training (Shohel et al., 2010). Teachers' lack of time, training, and interest are the main barriers for integrating technology into teaching. In another paper of Shohel \& Kirkwood, the results reveal that the implications for the teachers' professional development underlie in the technology-poor contexts. According to Darrel M. West and Joshua Bleiberg (2013), the best educational technologies enable teachers to do more with fewer resources. Moreover, Harrison and Thomas (2009) emphasized that the paradigm shift that took place is in the way "the people are learning languages independently through the use of a growing range of Webbased tools that are presented in the context of a more participatory framework". On the other hand, most of the students and the teachers, who have enough knowhow of educational technology facilities, fail due to a huge gap between the curriculum and material design with the utilization of CLT- based language learning. 
Computer lab with internet connectivity is available for the students in different colleges of the country but very view use them. According to Mahmuda (2016), the use of multimedia projector is very common in the English language classrooms of Bangladesh (p.258). This indicates that there is recognition of the importance of integrating technology in the teaching/learning of English. According to Chapelle (2003), technology is necessary to improve the language ability of students simultaneously inside and outside of the educational setting. Teachers who teach English as a second language recognize the students' need to use English away from the classroom in order to improve communicative competence. But till now the usage of technology is very limited comparatively and misbalancing the CLTA curriculum and materials to gain successful English language learning environment to improve communicative competence.

\section{Methodology and Procedures}

The study was conducted employing both qualitative and quantitative methods. Based on the objectives of the study, the researchers applied Mixed- Method approach to collect data and analyze the collected data. Qualitative method included in-depth interviews and quantitative method covered a questionnaire for the students and a structured interview for the teachers. The study was conducted at four colleges, two English Medium-Colleges and two BengaliMedium colleges randomly selected in Bangladesh. Eight EFL teachers and 250 higher secondary students studying English as their compulsory study subjects were selected as participants. Teachers and students were interviewed separately in a formal setting with a number of open-ended questions related to the technology they are using while learning in both educational institutions and at home.

In addition, an online survey on technology used in educational institution in English language learning was conducted to find out the validity of the interview and student's questionnaire. The data seems more or less the same except in some minor variations. The study was conducted in 2019.

\section{Results and Discussion}

It would be absolutely wrong if the use of technology is overlooked in any English language class in Bangladesh. With time the use of technology is increasing day by day. The common technological equipment that has been used in Higher Secondary level now-a-days are presented in Graph 1. 


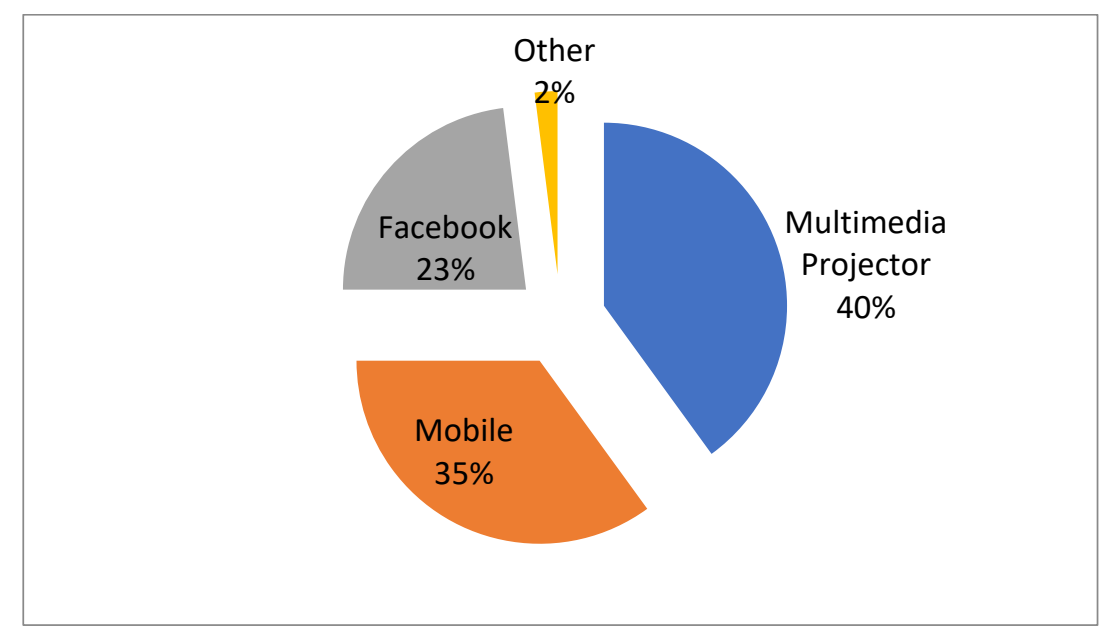

Graph 1: Technology in Use Education

Based on the survey that is done following the student's questionnaire and observation of the classroom both in English and Bengali (Version) colleges, all the data presented here are raw. As the survey shows, about 40 percent of the institutions are using multimedia in language class in regular basis, even the government of Bangladesh is putting emphasize on using multimedia projector-based class. Both teachers and students seemed to use mobile for dictionary use, checking out information and for many more educational purposes. As the pie chart shows, the use of mobile for educational purpose is 35 percent, the use of Facebook for educational purpose is 23 percent and whereas the use of other technological instruments is 2 percent. The detail discussions of use of the common technology are given in the following subsections:

\section{Multimedia Projector}

Multimedia is largely used in education and now-a-days it is a common tool in any classroom but not in a regular basis. By using technology in their classrooms, the teachers could easily capture attention, engage learners, explain difficult concepts, inspire creativity, and have fun. When using colourful presentation, static or dynamic multimedia, learners can visualize difficult concepts or procedures more easily. As classes in Bangladesh are usually congested with enormous number of student where teacher student ratio is almost 1:40, the use of multimedia does make the teaching more fruitful. About 61,000 teachers have been trained and many teachers are being trained through 500 trainers of public teachers' training colleges. "With the advent of the information and communication technology, the traditional teaching of 'Chalk \& Talk' is redesigned and supplemented by teaching with teacher-led multimedia content which is upgrading the education system. Refashioning classroom, creating a responsive and enabling learning environment, redesigning instructional materials and other learning aids are deemed to be an important part of the envisioned education reform" stated in a Govt. report by Education Ministry.

Colleges in Bangladesh are divided into two categories; English-Medium and BengaliMedium. The main difference between the two is that English-Medium colleges material and 
curriculum are designed in English except the Bengali textbook. The Bengali mediumcolleges materials and curriculum are designed in Bengali language except the English textbooks. The following Pearson correlation study presents the use of multimedia in both English-Medium and Bengali-Medium colleges:

Table 1: Use of Multimedia in colleges

\begin{tabular}{llr|r} 
& & $\begin{array}{c}\text { English } \\
\text { Version }\end{array}$ & \multicolumn{2}{c}{$\begin{array}{c}\text { Bengali } \\
\text { Version }\end{array}$} \\
\hline English Version & Pearson Correlation & 1 & $.612^{* *}$ \\
\cline { 2 - 4 } & Sig. (2-tailed) & & .000 \\
\cline { 2 - 4 } & $\mathrm{N}$ & 125 & 125 \\
\hline Bengali Version & Pearson Correlation & $.612^{* *}$ & 1 \\
\cline { 2 - 4 } & Sig. (2-tailed) & .000 & \\
\cline { 2 - 4 } & $\mathrm{N}$ & 125 & 125 \\
\hline
\end{tabular}

**. Correlation is significant at the 0.01 level (2-tailed).

Source: Authors

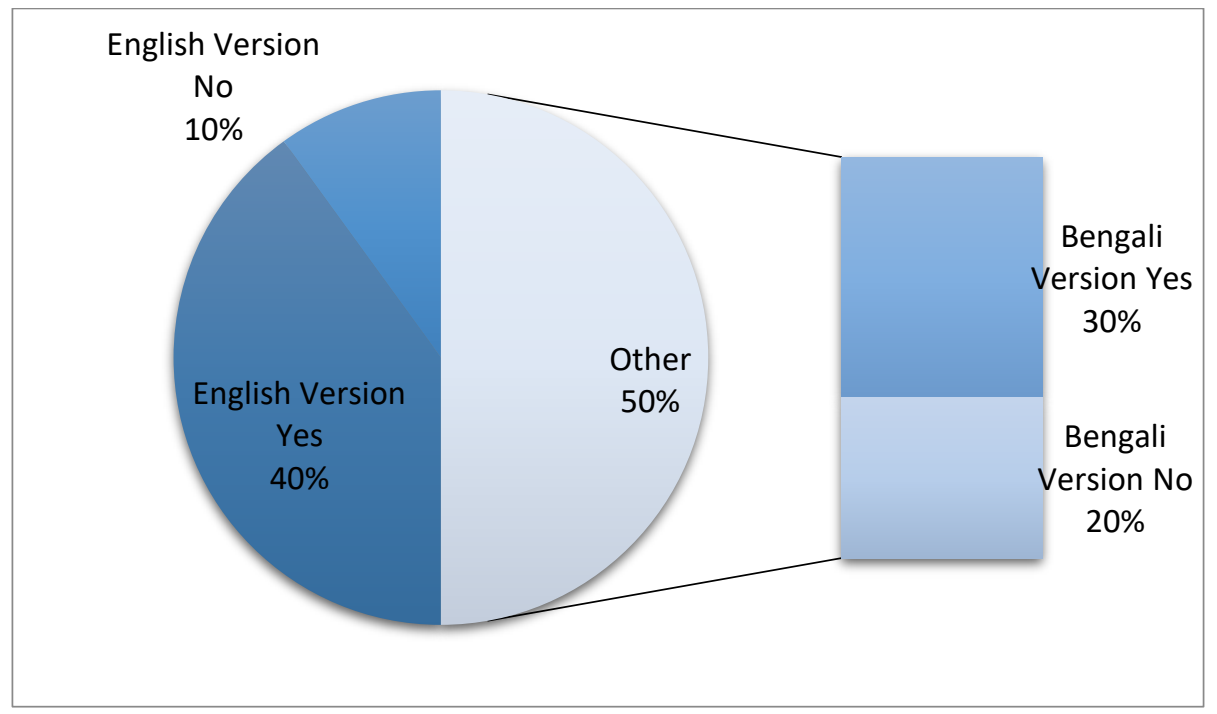

Graph 2: Use of Multimedia in colleges

Based on the interviews and class observation, it is found out that among the 125 students of English-medium colleges, most of the students agree that in language class multimedia is used. As the pie chart shows, 40 percent of the 125 English version students choose 'yes' and 10 percent voted for 'no' as they said not in all the classes of English language multimedia. In case of Bengali-Medium, the number varies based on institution. About 75 per cent agree that multimedia is used in their classrooms, while regarding the use of projector, the responses varied. As indicated, the use of this educational tool is not regularly.

\section{MALL}

Mobile Assisted Language Learning (MALL) is a mode of learning which takes place using content or interaction affordances facilitated by mobile devices such as cell phones, mp3 
players, notebooks, hand-held mini computers, PDAs, cameras, data storage devices and a number of other portable devices. More or less, almost all mobile devices have internet connection. Statistics present that almost $85 \%$ of mobile phones shipped worldwide by 2011 had internet browser on them and almost the pick of achieving the claim between that between 2010- 2018 web access via mobile will exceed desktop web access. Nowadays, it's pretty difficult to find a person without mobile and internet connection along with it. Based on the statistic of the number of mobile-cellular subscriptions in Bangladesh from 2000 to 2017 as in 2017, the number of mobile subscriptions in Bangladesh was at 145.11 million. Given this situation, learners can communicate with the teachers for any queries other than the classroom activities. Both teachers and learners can operate and watch many educational programs or talk on several TV channels of Bangladesh. These programs mostly focus on science and technology, agriculture, English language learning or tourism and directly can help both the learners and teachers. The following table presents the relationship of English and Bengali Version College's learners' use of mobile with internet connection:

Table 2: Students have mobile with Internet

\section{Correlations}

\begin{tabular}{llr|r} 
& & $\begin{array}{c}\text { English } \\
\text { Version }\end{array}$ & \multicolumn{2}{c}{$\begin{array}{c}\text { Bengali } \\
\text { Version }\end{array}$} \\
\hline English Version & Pearson Correlation & 1 & $.180^{*}$ \\
\cline { 2 - 4 } & Sig. (2-tailed) & & .045 \\
\cline { 2 - 4 } & $\mathrm{N}$ & 125 & 125 \\
\hline Bengali Version & Pearson Correlation & $.180^{*}$ & 1 \\
\cline { 2 - 4 } & Sig. (2-tailed) & .045 & \\
\cline { 2 - 4 } & $\mathrm{N}$ & 125 & 125 \\
\hline
\end{tabular}

*. Correlation is significant at the 0.05 level (2-tailed).

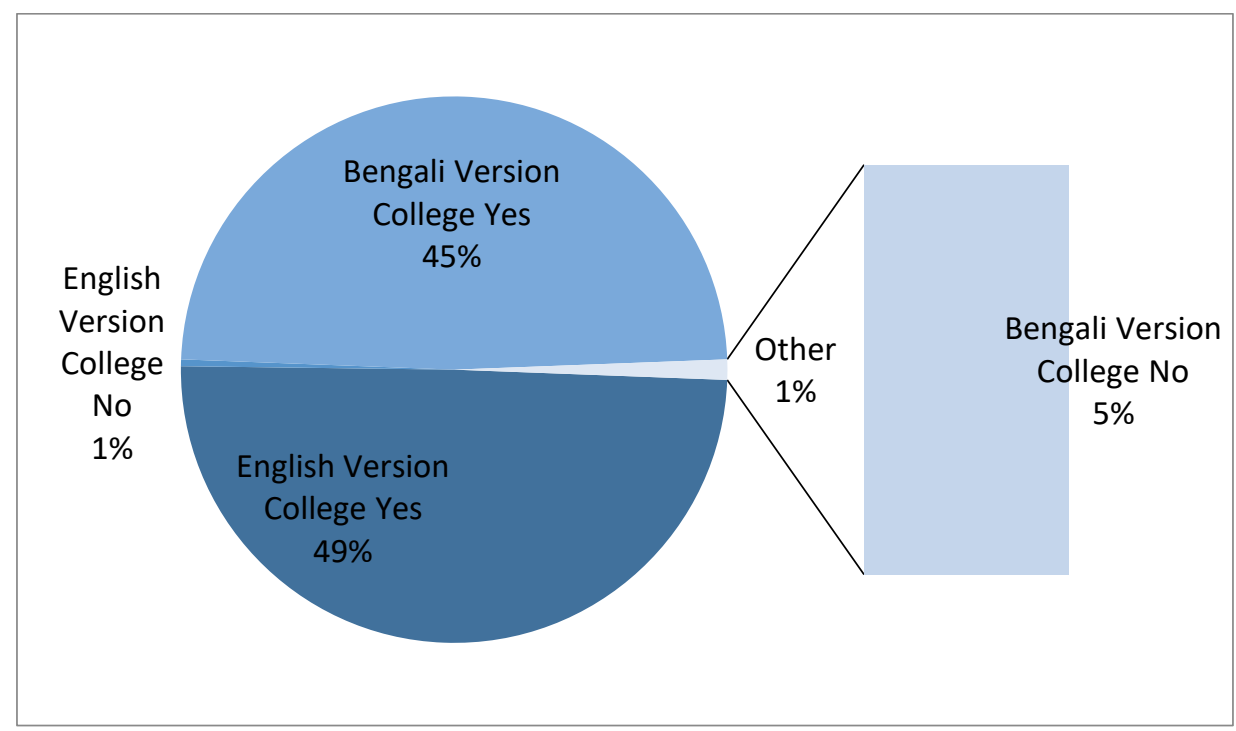

Graph 3: Students have Mobile with Internet 
As the questionnaire and class observation present the use of mobile with internet for educational purpose, almost all the students of English Version College's possessed mobiles with internet. But some colleges do forbid the use of mobile. Most of the students have android cell phone that they use in class especially for consulting some E-books, dictionary checking and getting information. As $49 \%$ of the respondents indicated that they have android mobile phones, 1 percent of the students still use analogue cells for casual usage. Most often the average student in Bangladesh including the students in the rural areas cannot afford buying smart mobile.

\section{Audio-visual Equipment:}

The use of audio visual equipment, specifically the audio equipment is not that much common in the classroom, but their CLT based designed materials and curriculum includes this technology. Some Government colleges, which are countable, get those audio clips due to the teacher training program but pretty rarely used as the teacher says its time consuming to practice those listening tasks. When asked about the use of Audio- visual equipment the students replies are presented below in relation to the English-Medium and Bengali-Medium Colleges:

\begin{tabular}{llrr} 
& \multicolumn{2}{c}{ Table 3: Use of Audio Clips } \\
& & $\begin{array}{c}\text { English } \\
\text { Version }\end{array}$ & \multicolumn{1}{c}{$\begin{array}{c}\text { Bengali } \\
\text { Version }\end{array}$} \\
\hline English Version & Pearson Correlation & 1 & $.476^{* *}$ \\
\cline { 2 - 4 } & Sig. (2-tailed) & 125 & .000 \\
\cline { 2 - 4 } & $\mathrm{N}$ & $.476^{* *}$ & 125 \\
\hline Bengali Version & Pearson Correlation & .000 & 1 \\
\cline { 2 - 4 } & Sig. (2-tailed) & 125 & 125 \\
\cline { 2 - 4 } & $\mathrm{N}$ &
\end{tabular}

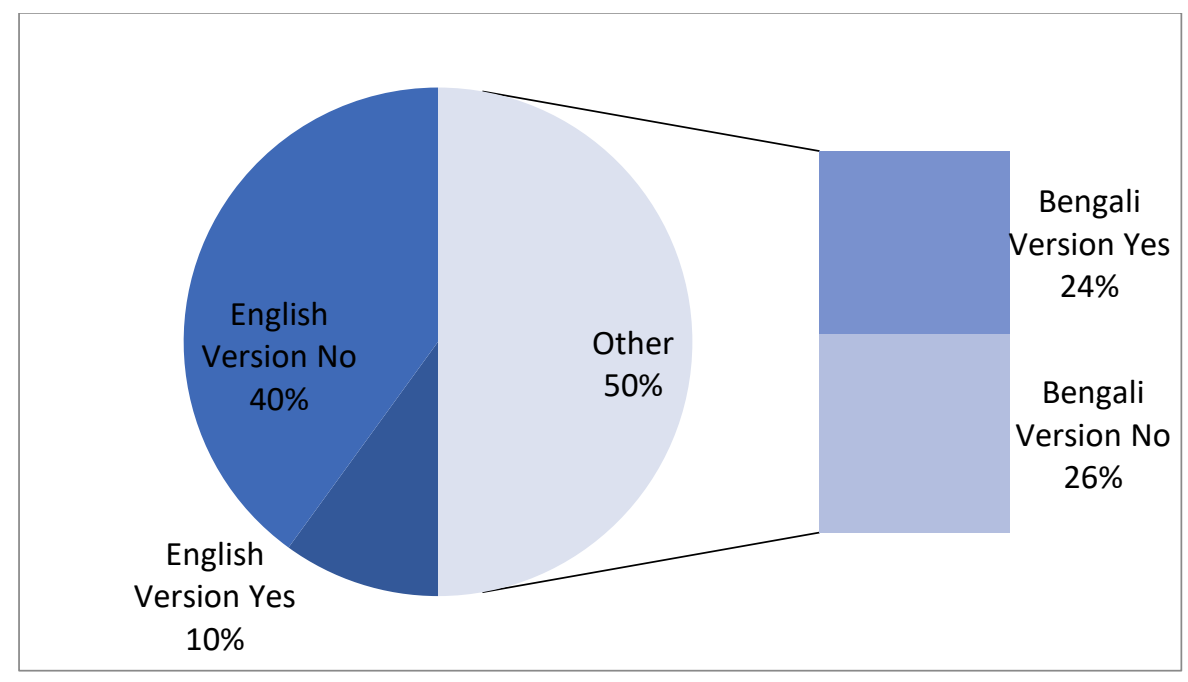

Graph 4: Use of Audio Clips 
Most of the English version colleges seem not to get those audio clips or rarely as the teachers got the opportunity to have training from teachers training centre. So, as the table presents, they mostly says no while asking about the use of audio clip in language class. But as maximum Bengali version colleges are Govt. College and the teachers seem to use audio clip as they have been trained under Govt. but not on regular basis. Almost 65 percent of the students replied with "No" when asked about the use of audio clips.

\section{Social Networking Websites}

Most of the social media websites' are in English. Social media websites have also grown in numbers by leaps and bounds. As per the statistics revealed, approximately 2 billion users used social networking sites and apps in 2015. With the increased use of mobile devices, this number is likely to cross the 2.6 billion mark by 2018. Different social networking websites like Facebook, twitter, Skype, YouTube, LinkedIn are also being used for teaching and learning. Although these sites are known mostly as entertainment sites, they are now used for educational purposes too. These sites are helping the students to remain connected even after the class. A teacher can easily get in touch with or send any notice to a particular group of students or can counsel the students personally. To see the relation of using different social sites used in education in Bangladesh the following table is presented:

Table 4: Social Sites that are used for Educational Purpose

\begin{tabular}{|c|c|c|c|c|c|c|}
\hline & & Facebook & YouTube & Twitter & Skype & Others \\
\hline \multirow[t]{3}{*}{ Facebook } & Pearson Correlation &.$^{\mathrm{a}}$ &.$^{\mathrm{a}}$ &. $\mathrm{a}$ &. $\mathrm{a}$ &. $\mathrm{a}$ \\
\hline & Sig. (2-tailed) & & & & . & \\
\hline & $\mathrm{N}$ & 250 & 250 & 250 & 250 & 250 \\
\hline \multirow[t]{3}{*}{ YouTube } & Pearson Correlation &.$^{a}$ & 1 & .013 & .013 & .117 \\
\hline & Sig. (2-tailed) & . & & .840 & .840 & .066 \\
\hline & $\mathrm{N}$ & 250 & 250 & 250 & 250 & 250 \\
\hline \multirow[t]{3}{*}{ Twitter } & Pearson Correlation &.$^{a}$ & .013 & 1 & $1.000^{* *}$ & .110 \\
\hline & Sig. (2-tailed) & . & .840 & & .000 & .083 \\
\hline & $\mathrm{N}$ & 250 & 250 & 250 & 250 & 250 \\
\hline \multirow[t]{3}{*}{ Skype } & Pearson Correlation &.$^{\mathrm{a}}$ & .013 & $1.000^{* *}$ & 1 & .110 \\
\hline & Sig. (2-tailed) & . & .840 & .000 & & .083 \\
\hline & $\mathrm{N}$ & 250 & 250 & 250 & 250 & 250 \\
\hline \multirow[t]{3}{*}{ Others } & Pearson Correlation &.$^{a}$ & .117 & .110 & .110 & 1 \\
\hline & Sig. (2-tailed) & . & .066 & .083 & .083 & \\
\hline & $\mathrm{N}$ & 250 & 250 & 250 & 250 & 250 \\
\hline
\end{tabular}

**. Correlation is significant at the 0.01 level (2-tailed).

a. Cannot be computed because at least one of the variables is constant. 


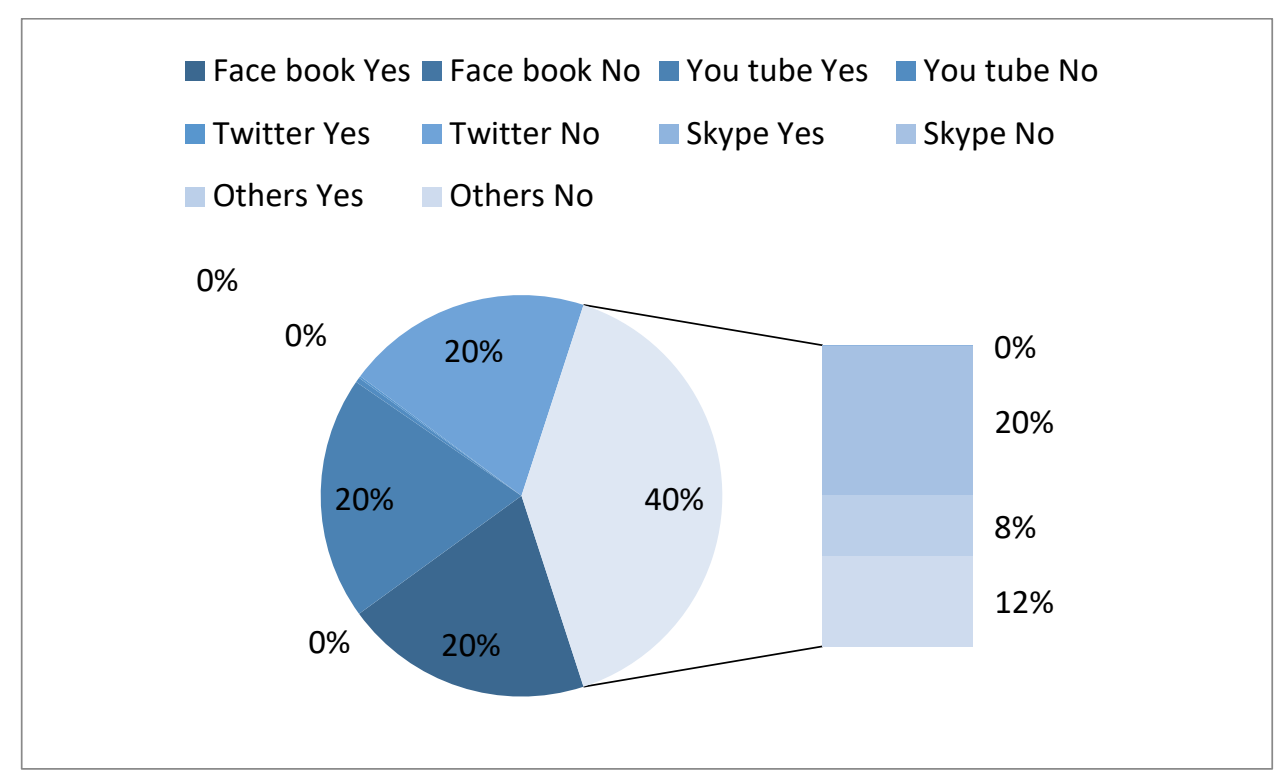

Graph 5: Social Sites that are used for Educational Purpose

Facebook is the most common and famous of all sites where there are several groups of H.S.C students and teachers. In those groups, they help each other and learn collaboratively. The next questionnaire was on the use of Social Media for educational purposes. The responses showed nonconformity. Almost all the 250 students of both English and Bengali version colleges revealed that they use Facebook for educational purpose besides using it as a source of chatting and as an entertainment source. Most of the student indicated they have groups for discussing any problem or finding any solution by interacting virtually via Facebook. They also state that they are part of different groups where most of the college students help each other. Some of the students indicated that they most of the time use English as a medium of communicating with others. This can also be considered as use of Facebook for improving their English.

Teaching and learning videos are also available in YouTube. Different classroom activities are also found in YouTube. Use of YouTube for educational purpose is a question where most of the students agree that they do watch the educational videos available in YouTube. Especially they point out that they watch in order to learn grammar if they don't understand from the teacher in class. They also indicated that their teacher brings multimedia to show them certain videos and audios that are relevant to their English classes.

Twitter and Skype are also other popular social media outlets like Facebook. They are used by most of the students of Bangladesh, but they seem to use it as a way to socializing rather than using it for education. There are other Social Media platforms that the students use but the students seem to use them rarely. Although many learners seem to use English in chatting in social media but they most often type only the short form of English vocabulary which affects their leaning. In this way, they use wrong English which creates bad impact on them.

In H.S.C level students already have enough knowledge about English vocabulary, so the use of technology can be easily understandable rather than any other level. Technology has been 
used in our education system of college level but that's very still limited. In H.S.C level, the use of technology may vary but the tools can be used in teaching to make teaching more fruitful and enjoyable.

\section{CALL:}

CALL or Computer Assisted Language Learning is a common way of learning language. It is briefly defined in a seminal work by Levy $(1997, \mathrm{p} .1)$ as "the search for and study of applications of the computer in language teaching and learning". Means involvement of computer in learning will fall under the horizon of CALL. From 1990s, it has become increasingly difficult to categorizes CALL as it is now extending to the use of blogs, wikis, social networking, podcasting, Web 2.0 applications, language learning in virtual worlds and interactive whiteboards.(Davies et al. 2010 ).

The use of CALL in H.S.C level especially in classroom is now-a-days available due to the use of projector. Apart from that computerized lesson plan, lesson content sometimes teacher shows to make the lesson easy. The following table presents the use of CALL application in relation to other applications.

Table: 5 Use of CALL

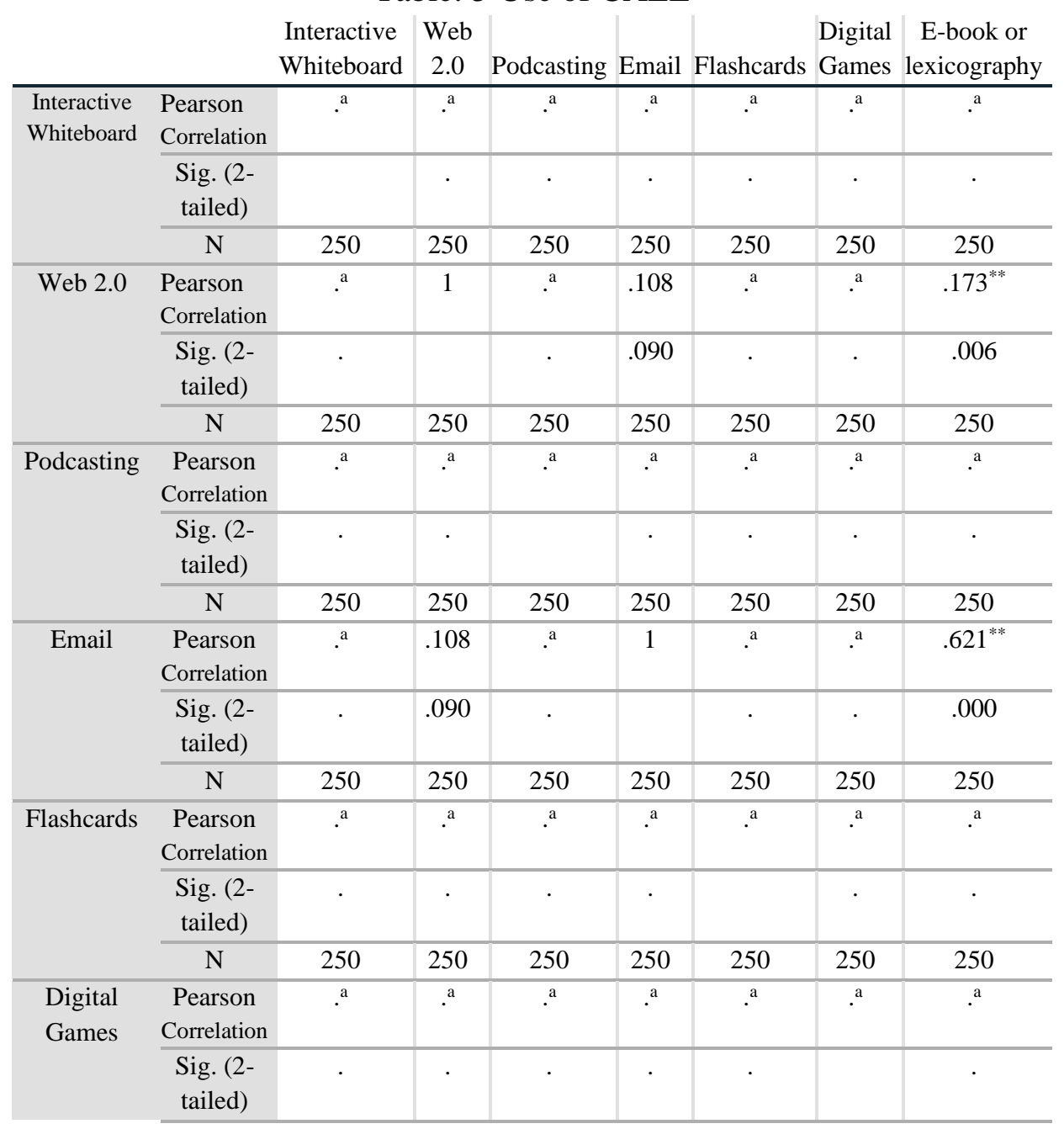




\begin{tabular}{|cc|c|c|c|c|c|c|c}
\hline $\mathrm{N}$ & 250 & 250 & 250 & 250 & 250 & 250 & 250 \\
\hline $\begin{array}{c}\text { E-book or } \\
\text { lexicography }\end{array}$ & $\begin{array}{c}\text { Pearson } \\
\text { Correlation }\end{array}$ & $\cdot^{\mathrm{a}}$ & $.173^{* *}$ & $\cdot^{\mathrm{a}}$ & $.621^{* *}$ &.$^{\mathrm{a}}$ & $\cdot^{\mathrm{a}}$ & 1 \\
$\begin{array}{c}\text { Sig. }(2- \\
\text { tailed) }\end{array}$ & $\cdot$ & .006 & $\cdot$ & .000 & $\cdot$ & $\cdot$ & \\
\hline $\mathrm{N}$ & 250 & 250 & 250 & 250 & 250 & 250 & 250 \\
\hline
\end{tabular}

**. Correlation is significant at the 0.01 level (2-tailed).

a. Cannot be computed because at least one of the variables is constant.

Source: Authors

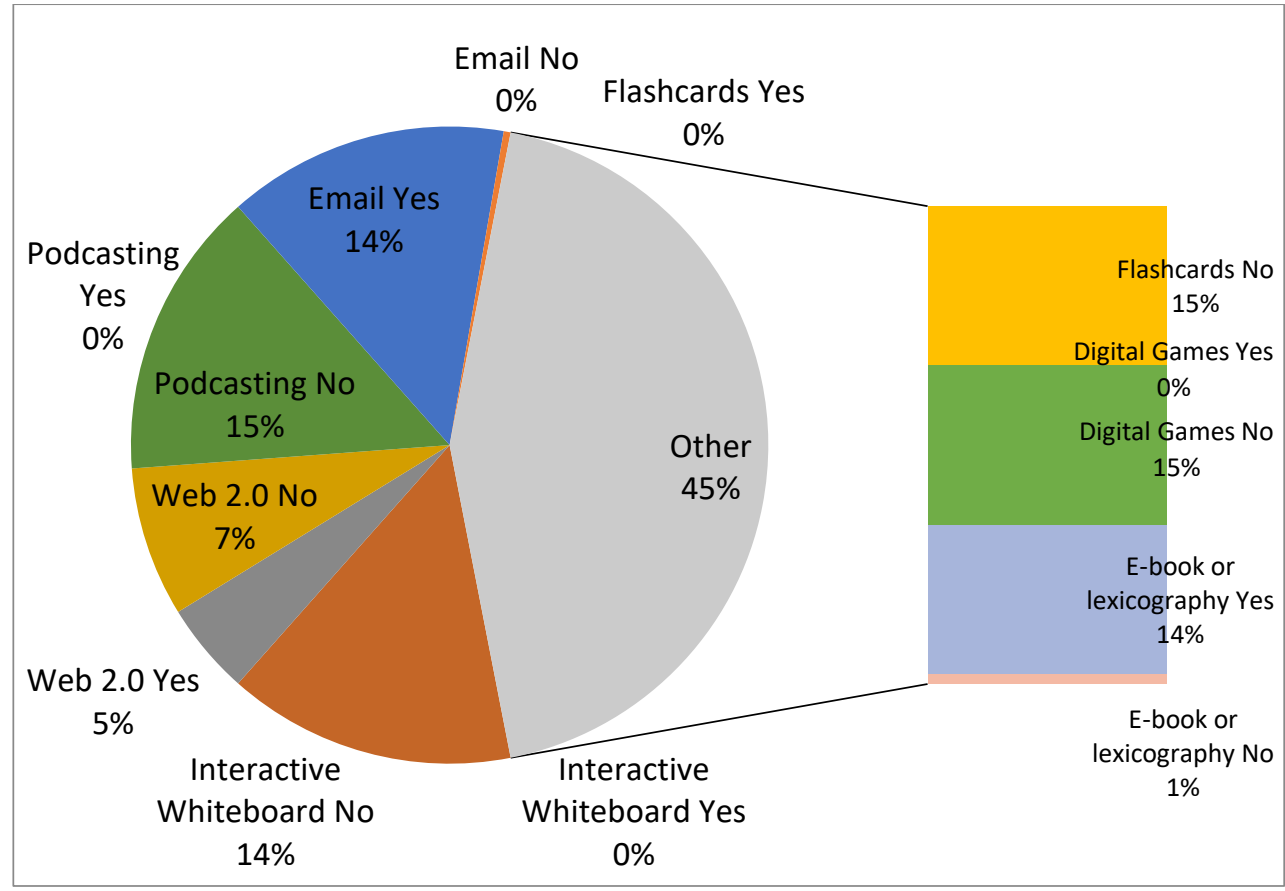

Graph 6: Use of CALL

Based on the responses, the use of interactive whiteboard is not available in Bangladesh for educational purpose. When asked about the use of web2.0 that includes blogs, webs, wikis, 80 students responded positively but others disagree as they say they don't use them for educational purpose rather as a social site or checks casually. Podcasting is also a new technology that the students seem not to know or hear about. The majority of the respondents indicated that they don't use podcasting for language learning. Emailing is a common term that is known to all, but the students' response is negative. Most of them indicated that they never really send emails to anyone but they know about this technology.

The use of flashcard is common in any language class but it seems that most of the students and teachers do not know anything about flashcards in classroom for language teaching. They even do not know how flashcards can help in language learning. Digital games can play an important role in language learning class. Nevertheless, the results of the questionnaire show that students have never been acquainted with this term before in connection to education. Overall, it is clear that in H.S.C level technology is not yet welcomed in its full speed but students are learning to employ educational technology in learning English. 


\section{Discussion}

From the above data analysis, it is clear that the use of technology in Bangladesh is increasing day by day but the percentage is still very low. To enhance the use of technology and establish the project of Government of Bangladesh, we can ensure an ideal education system. As it's a common issue not only in Bangladesh but also in other Asian countries, the learners experience a kind of 'English Phobia'. With the proper use of the technology as presented above, teachers can make every English Language teaching class more interesting. With technology, probably the learners would feel comfortable to learn English without keeping any phobia. In language teaching class, the use of flash card and also the flash card game in computer can help any learners to learn the vocabulary much easily following CLTA, rather memorizing. If computer is not available, teachers can suggest using mobile. Both teachers and students should be creative and employ any possible means that can help in advancing the teaching/learning process.

\section{Conclusion and Suggestion}

The study examined the use of educational technology in EFL classes in Bangladesh. Though the Government of Bangladesh emphasizes on the use of technology in every sphere of life to achieve the vision of Digital Bangladesh, the results of this study indicate that there is a gap between the use of technology and CLT-based curriculum and material in Bangladesh. Due to some limitations, many educational technologies have not been integrated into the classrooms. Hence, it is concluded that the technologies that are used in the classrooms are not adequate. The curriculum must be upgraded to accommodate the new technological changes. In addition, the training of teachers and the integration of CLT into English classrooms would enrich the teaching/learning process and bring about good educational outcomes. The teachers are not yet well-trained and more often not able to handle modern technologies too. Finally, this study suggests that the complete use of certain technology and training of teachers for the proper implementation of technologies can lead the students to have a bright future to build a bright nation.

\section{Acknowledgement}

This research was supported and developed by the researchers' supervisor Ass. Professor Wu Jidong. We thank our colleagues from Bangladesh who helped us to collect the data from Bangladesh and provided insight and expertise that greatly assisted the research. We would also like to show our gratitude to our present classmates who gave us some new ideas to think and act accordingly for the paper. I would like also thank 'anonymous' reviewers for their insights.

\section{Conflict of Interest}

The authors of the article declare no conflict of interest. 


\section{Funding}

This research study was not funded by any institution. The authors conducted the study on their own expenses.

\section{References}

Afrin, N. (2014). Integrating computer assisted instruction in the EFL Classroom of Bangladesh. OSR Journal of Humanities and Social Science, 19(11), 69-75.

Ahmed, S. T. S. (2019). Chat and Learn: Effectiveness of Using WhatsApp as a Pedagogical Tool to Enhance EFL Learners Reading and Writing Skills. International Journal of English Language and Literature Studies, 8(2), 61-68.

Blattner, G., \& Fiori, M. (2009). Facebook in the language classroom: Promises and Possibilities. International Journal of Instructional Technology and Distance Learning, 6(1), 17-28.

Daniel, J. (2013). Audio-visual aids in teaching of English. International Journal of Innovative Research in Science, Engineering and Technology, 2(8), 3811-3814.

Ellis, Rod (1985). Understanding Second Language Acquisition. Oxford: Oxford University Press.

Hiew, W. (2012). English Language Teaching And Learning Issues In Malaysia: Learners'perceptions Via Facebook Dialogue Journal. Researchers World, 3(1), 11.

Ivy, T. (I.(2012). Technology and the language teacher. Arts Faculty Journal,4, 206-223.doi: http://dx.doi.org/10.3329/afj.v4i0.12942

Khan, M. S. H., Hasan, M., \& Clement, C. K. (2012). Barriers to the introduction of ICT into education in developing countries: The example of Bangladesh. International Journal of instruction, 5(2).

Maniruzzaman, M. \& M.M. Rahman. (2008). The use of audio aids in the EFL Class at the tertiary level: A plus or a minus? Daffodil University International Journal of Business and Economics, Vol. 3 (1), 121-137

Morrison, G. R. \& Lowther, D. L. (2010). Integrating Computer Technology into the Classroom Rahman, J. (2015). CALL and English at tertiary level: Teacher cognition in Bangladesh (Master's thesis, Macquarie University, Sydney, Australia). Retrieved from https://www.researchonline.mq.edu.au/vital/access/services/Download/mq: 44498/SOUR CE1

Rahman, K. S., Paul, J. R., \& Hasan, M. K. (2012). ICTs in the field of education in Bangladesh: Some salient features. Elixir International Journal, 47, 8977-8985. Retrieved from http://www. elixirpublishers.com/articles/1351170244_47\% 20(2012)\%208977-8985.pdf

Sharma, R. C. (2003). Barriers in using technology for education in developing countries. In International Conference on Information Technology: Research and Education, 2003. Proceedings. ITRE2003. (pp. 512-516).

Shohel, M. Mahruf C. and Power, Tom (2010). Introducing mobile technology for enhancing 
teaching and learning in Bangladesh: teacher perspectives. Open Learning: The Journal of Open and Distance Learning, 25(3) pp. 201-215.

Shohel, M. M. C., \& Kirkwood, A. (2012). Using technology for enhancing teaching and learning in Bangladesh: challenges and consequences. Learning, Media and Technology, 37(4), 414-428.

Ullrich, C., Borau, K., \& Stepanyan, K. (2010). Who students interact with? a social network analysis perspective on the use of twitter in language learning. In European Conference on Technology Enhanced Learning (pp. 432-437). Springer, Berlin, Heidelberg

Tozcu. Anjel, (2008), "The use of interactive whiteboards in teaching non-roman scripts", Computer Assisted Language Learning.

Tozcu, A. (2008). The use of interactive whiteboards in teaching non-roman scripts. Computer Assisted Language Learning, 21(2), 143-166.

Zhu, Y., Fung, A. S., \& Wang, H. (2012). Memorization effects of pronunciation and stroke order animation in digital flashcards. CALICO Journal, 29(3), 563-577. 